\title{
The Culture of Business Education and Its Place in the Modern University
}

Russell A. Evans

Queen's University

\begin{abstract}
Many researchers believe that the modern university is in a state of crisis like never before. One of the main reasons cited for this decline is that the modern university has a closer resemblance to a transnational corporation than to a traditional scholarly institution (Lewis, 2005). This paper attempts to define the term "university" from a classical perspective and to describe the gradual incorporation of vocational pursuits into its scope. Focusing on modern North American university models, it asks whether business schools, in particular, should be operating within academia. An alternative is discussed, which focuses on the vocational attributes of business rather than theoretical knowledge. I draw on secondary sources as well as my own personal experience as a student and researcher to make suggestions on how interdepartmental tension developed and how it can be reduced. The paper finds that the business school does have a place in the modern university; however, the classical representation of the university must be abandoned for it to be fully embraced.
\end{abstract}

\section{Résumé}

De nombreux chercheurs croient que l'université moderne n’a jamais vécu une crise si grave. Une des principales raisons citées pour expliquer cette baisse est que l'université moderne ressemble plus à une entreprise transnationale qu'à un établissement d'enseignement scientifique traditionnel (Lewis, 2005). Le présent article tente de définir le terme « université » selon une perspective classique, et de décrire ce qu'est l'intégration progressive d'une carrière professionnelle dans son champ d'application. Se concentrant sur les modèles universitaires modernes en Amérique du Nord, on demande si les écoles commerciales, en particulier, devraient fonctionner en milieu universitaire. 
On discute d'une alternative qui mise sur les attributs professionnels du commerce plutôt que sur les connaissances théoriques. Nous tirerons parti des sources secondaires aussi bien que de ma propre expérience en tant qu'étudiant et chercheur pour apporter des suggestions sur la façon dont la tension interdépartementale s'est créée et les moyens de la réduire. Notre recherche constate que l'école de commerce a bien une place dans l'université moderne, cependant, afin que cette place soit pleinement assumée, il est nécessaire d'abandonner la représentation classique del'université en général.

\section{Introduction}

According to many scholars, universities are in a state of crisis unlike any seen in the past (Pelikan, 1992; Readings, 1996; Emberley, 1997). Government cutbacks, striking staff, research falsification, and administrative blunders have all pointed to a bleak future for the university model (Emberley, 1997). Emberley believes that the university is under siege from both the "corporate right" and the "cultural left," which collectively threaten to unhinge the university from its historical development. Others believe the modern university has a closer resemblance to transnational corporations than to the traditional and classical images of a scholarly institution (Lewis, 2005).

The traditional university, envisioned centuries ago by the scholar Wilhelm von Humboldt, was a place where research would be conducted independently of social and political interests, but it now seems to have been buried by a sea of strategic objectives and operational goals (Bahti, 1992). Universities have become more vocational over the past century, due to the demand for, and subsequent proliferation of, professional schools. These include the schools of medicine, law, engineering, and business. The business school is particularly interesting because it has the most potential to alter the overall direction of a university. Operations management, accounting, organizational behaviour, strategy, and finance, all subdisciplines of a business education, have also become critical to making the administration of a university possible. Despite business schools being integral in the raising of revenue, setting of strategy, and reporting of finances, many believe they are a contributing cause of the academic crisis of identity in North America (Emberley, 1997; Pelikan, 1992; Readings, 1996).

When one thinks of the term "university," the meaning is not always clear. The Merriam-Webster dictionary defines a university as "an educational institution designed for the instruction and examination of students in many branches of advanced learning." This definition is very broad and some prefer to define "university" in a classical sense. To them, the university represents a space where thought and inquiry are employed in the pursuit and dissemination of knowledge (Kerr, 1963). Furthermore, they believe that the research and teaching of knowledge in a university should be independent of social, economic, or political influence (Lewis, 2005). These academics consider business schools to be vocational schools and therefore not part of the scope of a university education (Carson, 1999). The argument they present is that the subdisciplines that define a business education, such as finance, accounting, and operations, are providing a practical set of skills and do not belong within a predominantly theory-oriented university (Boothman, 2000a). For this reason, they argue, business schools more closely resemble vocational institutes, or polytechnics, and should be housed there (Emberley, 1997). 
Nearly every field of study contains a tension between theory and practice (Sirotnik, 1991). Education is no different. Epistemologically, theory and practice can be viewed as theoretical knowledge and practical knowledge. Each has their own value; theory for its generalizability and practice for its experience and skill. Theory could be said to reside primarily in academia (the world of scholarly culture) while practice can be said to reside in the real world (the realm of actual experience). Action, however, can be said to reside in both academia and the real world, thus bridging theory and practice. Bach (2010) notes this by stating that action influences theory and theory influences practice. This means that practice and theory have a symbiotic, reciprocal relationship that is mutually beneficial, and both are influenced by action. In order for this relationship to work, a period of self-reflection must occur after each action, to see how theory as well as future practice may be influenced (Sirotnik, 1991).

In the case of business schools in North America, however, they do not include any critical self-reflection and build curricula based solely on skills required by industry (Craig, Clarke, \& Amernic, 1999). Making this problem worse, business students rarely question the curriculum being administered to them or contribute to its content in any meaningful way (Bach, 2010). They do not critically reflect upon the information they are required to learn before applying it in the business world. The act of critically reflecting on the actions that one performs in order to improve future outcomes is referred to as praxis (Bach, 2010). In terms of specific learning outcomes, praxis allows students and educators to improve curricula through cycles of action and reflection. In business schools, however, praxis is not prevalent and actions are not critically analyzed or reflected upon before being repeated. This lack of praxis is likely why social or political critiques of capitalist economic systems are very rare in business school curricula (MacIntosh, 2002).

The treatment of theory in business schools has a similar, uncritical basis. Business research does not create its own theoretical explanations; instead it borrows theories from other disciplines such as sociology, politics, and economics (Durand \& Dameron, 2008).

Most North American business schools use the assumptions of neoclassical economics to explain human behaviour in capitalist economies (Howard, Lorange, \& Sheth, 2013). Also, the research produced by business schools is generally positivistic, economics-based, and built on a foundation of scientific rigour (Slaughter \& Leslie 1997). For instance, the majority of accounting research is focused on financial market efficiency, financial statement analysis, and employee efficiency (MacIntosh, 2002). Only a very small portion of the published research coming out of business schools in North America is critical of the social and cultural implications of business practices or of capitalist economies (Grey 2007; Howard, et al., 2013).

One could argue that critical self-reflection is a necessity in the pursuit of truth and without it you are not furthering knowledge (Freire, 2000). The question being asked in this paper is whether the shortage of self-reflective curricula and critical research are indications that business schools might not belong in a university. Also, how have these conditions affected the current standing of business schools within the overall university community?

\section{What Is a University?}

The conventional understanding of the modern university began with Wilhelm von Humboldt's teaching and research model that he implemented at the University of Ber- 
lin in 1809 (Howard, et al., 2013). These universities allowed students the opportunity to pursue knowledge in a scholarly setting with a minimal amount of distraction. Many of us think of universities as centres of study accommodated in limestone buildings populated by professors in smoking jackets and students bustling from class to class carrying textbooks. These images are created through personal experience or through images found in media and popular culture (Derrida, 1992). These idealized images, or signs, do not tell the history, politics, or struggles of the actual events that have taken place within the limestone walls. A "sign" exists exclusively in our minds and is based on something in the real world called a "referent." As described by Ferdinand de Saussure in his study of semiotics, each sign has two parts: the signified and signifier (MacIntosh, 2002). In this case the referent is the university but the sign created in our mind is not actually real, it is hyper-real. Being hyper-real means that the sign no longer refers to something that is real, it refers to another sign, existing only in our mind that once originated in reality (MacIntosh, 2002).

No exemplar referent of the university exists that encompasses all characteristics of "university-ness" for all people. When we hear or see the signifier "university," it conjures up a plethora of different ideas and meanings, or "signifieds," depending on the individual's perception. These differences are a result of contextual differences between various people's experiences. Roland Barthes expanded this idea by discussing complex and differential words like "university" in terms of primary order and secondary order of signifieds (MacIntosh, 2002). A primary order signifier "university" may be the postsecondary school a person attended or the stylized images of Harvard University on a brochure. Second order signs of "university" may include other concepts such as "academia," "research," "intelligence," or "bureaucracy." The "university" is a very complex concept that encompass broad perceptions and imagery and various meanings of the term that have been proposed.

According to scholars like Emberley (1997) and Oakeshott (1972), the idea of the university cannot and should not be understood outside of its historical context. Emberley (1997) has two conceptions of the university; universitas and civitas. The principal commitments of universitas are the pursuit of knowledge and objective truth. Civitas has more to do with an atmosphere of civility, dialogue, and productive debate that exists within a university. Putting these together, the university is a space where the pursuit of knowledge and truth occur and the atmosphere is one of mutual respect and civility. According to Emberley (1997), this combination of universitas and civitas is referred to as a "scholarly culture." Carson (1999) sums up the main characteristics of Emberley's 1997 definition of the university:

- students are initiated into the scholarly culture

- education is a process without ends or objectives

- reading and conversation form this process

- the value derived from a university education is inherent, not instrumental

- education is detached from the worries of day to day life

- the commitment is to objectivity of knowledge and pursuit of truth

- civility is important to the functioning of academic communities (Carson, 1999, p. 181)

Like Carson (1999; 2007), other scholars (Bahti, 1992; Readings, 1996; Barnett, 2000) believe the modern university does not encompass the attributes laid out by Emberley (1997) and Oakeshott (1972). Differences exist among scholars about what disciplines 
should be included in the university model and to what extent curriculum should focus on practical skills versus the pursuit of new knowledge and truths. A surprising number of policy makers, government officials, and academics believe the role of the university should be to prepare students for the working world (Emberley, 1997). This view breaks with the historical or classical definition of the university envisioned by von Humboldt and is always heatedly debated in academic politics.

Over the last few hundred years we have witnessed a transformation of the university from its historical, or traditional, representation into an institution that is more comprehensive and pragmatic (Bahti, 1992). One side of the debate believes that a university education should be critical, reflective, and based on the pursuit of knowledge and truth. The other side believes that the university should prepare its students to be productive citizens of society by learning pragmatic skills and applicable knowledge.

\section{An Overview of Contemporary University Models}

Four different concepts of the "real" university exist, according to Carson (2007). These include the college model, the research university, land grant universities and the "multiversity." These concept names are independent of regional differences that refer to institutions for post-secondary education. For instance, despite the influence that the United States has had on Canadian higher learning, the "college" model in the United States represents different terminology from that found in Canada. In the United States, a college refers to an institution that has much in common with a Canadian university, whereas, colleges in Canada focus heavily on vocational education and training students for the job market as their main objective (Boothman, 200ob).

According to Carson (2007), the college model is the oldest and most idealistic view of what the university should be. Its primary tenet is that a university education should be removed from the influences of everyday life, where extending knowledge, developing good judgement, and encouraging creativity are paramount to all other pursuits. Vocational pursuits and applied research would not be included in this model.

The research university, the second model, which originated in Germany with Wilhelm von Humboldt in 1809, pushes the pursuits of teaching and research as the primary activities within the university. This model promotes the discovery and creation of new knowledge; however, only knowledge with inherent value is included, and practical or vocational knowledge is excluded. Both the college and research models excluded any education that prepared the students for vocations or working life.

The third major model of the university developed in the United States in the midnineteenth century and represented a major shift in the defined mandate of the university. The Morrill Act of 1862, also known as the Land Grant College Act, spawned the creation of the institution called the land grant university. These universities were created in each state to train people to join the workforce in vocational fields such as agriculture or mechanics. The act was introduced by Justin Smith Morrill, a Vermont congressman, who wanted to provide postsecondary educational opportunities for all social classes (Carson, 2007). This marked the first time that these so-called "impure" vocational pursuits were included in the United States college model. Initially met with rejection, vocational education was eventually accepted as part of the college model by the majority of the scholarly community in the United States. 
The final model, as described by Barnett (2000), is a university of shifting epistemologies, complex conceptual frameworks, and blurred lines between disciplines. Barnett's view is that the university has become so complicated that the idea of describing a singular concept that includes all of its many facets is simply impossible. The university is simply a site where epistemological mayhem occurs and does not have a single meaning of its own any longer. As a result, the goals of the university shift again to create an environment where disciplines co-exist, scholarship can be pursued, the self can be improved, and dissenting opinions can safely have a voice.

Depending on which of these four models one subscribes to, it is not difficult to see where proponents and opponents of including the business school in the university model may derive their views.

\section{Business Schools}

How does the business school align with the university models described above? Business schools became part of the university landscape in the late-19th and early-20th centuries. As indicated by the legislation of the Morrill Act (1862), more individuals knowledgeable in business operations (specifically agriculture and mechanics) were needed (Carson, 1999). Land grant universities provided the venue for these skills to be developed. However, the number of students who pursued an education in business over the following decades was still limited. This was because the majority of business training continued to be conducted on the job or within family businesses (Bliss, 1987).

A shift occurred after World War II because of the dramatic increase in industry and population that occurred in North America. More and more people were seeking jobs and a postsecondary education provided a competitive advantage. Bliss (1987) notes that an explosion occurred in the number of people interested in a business education in North America throughout the 1960 s and 1970s. During the period from 1970 to 1990, the number of overall degrees in all universities in Canada doubled but this increase was outpaced by the number of business degrees that were awarded in Canada, which increased by 4.5 times over the same period (Carson, 1999). Not all business degrees are awarded at public universities, however (Carson, 2007). For-profit business school examples from the United States include the University of Phoenix, Walden University, and DeVry University (Tierney \& Hentschke, 2007). In Canada, for-profit universities have experienced both success and failure, see Lansbridge University ${ }^{1}$ (now closed), Meritus University ${ }^{2}$ (now closed), and the University Canada West ${ }^{3}$ (successful).

Business schools in North America have been established as a result of similar educational and institutional aspirations: to train business leaders in management, to shape management practice and to build its own body of knowledge using accepted scientific methods (Howard, et al., 2013; Durand \& Dameron, 2008). Creating a body of knowledge accepted as scholarly research is, arguably, the business school's largest hurdle to becoming fully accepted within academia. Furthermore their relationship with the corporate world positions them as both an insider and outsider to the rest of the academic world, and this is a significant hindrance in their search for scholarly legitimacy (Daub \& Buchan, 1999).

Peer-reviewed business journals and research-based degrees are some of the ways they attempt to legitimize themselves as academic insiders (Durand \& Dameron, 2008). However, research activities are money losers for business schools even though they 
are critical in attracting funding and building an academic reputation. Undergraduate programs are generally also money losers for the business schools so they must generate most of their revenue from Master of Business Administration (MBA) and executive training programs (Carson, 2007). The high tuition fees associated with these programs projects the message that revenue generation is the objective, rather than the pursuit of truth and knowledge. For instance, the top 20 MBA programs in the United States charge around $\$ 100,000$ in tuition fees, with some executive MBA programs reaching as high as $\$ 172,000$ (Howard et al., 2013). Some business schools have actually rid themselves of the undergraduate burden, such as IMD (International Institute for Management Development) in Lausanne, Switzerland and IE (Instituto de Empresa) in Madrid, Spain (Durand \& Dameron, 2008).

The high cost of MBA programs represents the commodification of education that has occurred within business schools and has resulted in a problematic relationship with other university faculties (Barnett, 2000). The issue of commodification of education has been occurring within almost all institutions of higher learning over the last few decades (Lewis, 2005). Many academics believe, however, it was the business school that pioneered the transformation of higher education into a commodity to be bought and sold to consumers (Tierney \& Hentschke, 2007). The foundation for this belief is that the business school has transformed education into a product so successfully that it has influenced other faculties within the university to do the same (Howard, et al., 2013).

\section{Commodification of the Business Degree}

Commodification implies an item that did not have any economic value assigned prior to being offered for sale (Lawrence \& Sharma, 2002). The commodification of education is based on free-market ideals of efficiency and cost effectiveness that have been transplanted into public universities over the past 30 to 40 years (Lawrence \& Sharma, 2002). The commodification of business degrees has led business schools to become revenuegenerating assembly lines of future managers, destined for the business world. Acquiring a business degree is no longer about getting an education for the values inherent in learning; it is about meeting the requirements set out by the government and corporations to ensure the vocational aptitude of students (Tilak, 2008; Tierney \& Hentschke, 2007). Thomas et al. (2013) summarize this idea succinctly by stating that the business school has become no more than a "finishing school" (p. 65). This only adds to the fear by many academics that students no longer go to business school to receive an education; they go to buy a degree (Howard et al., 2013).

In an age of globalization, universities have become masters of recruitment and marketing. We see the buzzwords everywhere claiming the best possible education, one that is unique, offers the peak of excellence, and will result in the highest salary after graduation (Pelikan, 1992). This is especially true in the business school. All one has to do is look at any MBA rankings to see how important reputation and marketing are to business schools and how they perpetuate the commodification of education. Business schools propose an educational experience that will give students an edge, or competitive advantage, when they hit the job market, and they have done this very well. They have created high demand and marketability, which in turn has led to higher tuitions and greater revenue (Tierney \& Hentschke, 2007; Lewis, 2005). 
Universities have been more and more commoditized in developed countries since the 1980 os because of education reforms and new public management ideologies (Lawrence \& Sharma, 2002). Business schools saw commoditization as an opportunity to generate revenue through increased enrolment and higher fees (Craig et al., 1999). The university, in general, has seen an increase in students desiring degrees and more graduates entering the workforce since about 1950 (Pelikan, 1992). The output of graduates from business schools has epitomized this trend by increasing enrolment through program flexibility and offerings. Also, there has been an effective marketing push promoting the value of the "business degree" (Howard et al., 2013).

To some, business schools have become training centres for corporations. To others, they are simply providing marketable skills that will set graduates apart once they enter the job market (Tierney \& Hentschke, 2007). Business schools want to be able to claim the highest employment rate and the highest salaries for its graduates in order to maximize reputation and attract the best incoming students (Durand \& Dameron, 2008). This has led to many schools forming partnerships with companies and industries in order to promote the hiring of their graduates (Boothman, 200ob). Also, according to Slaughter \& Leslie (1997) and Tilak (2008), governments have also been using university rankings and student success as a means to pursue global economic competitiveness for attracting international talent and trade from other countries. These relationships with markets and governments lead to very specialized curricula and a potential loss of autonomy for the business school itself.

Historically, this is not in opposition to the trade school model of business schools that was the dominant ideology up to 1960 . However, the commoditization of business degrees is in opposition to changes in the business school since the Ford and Carnegie Foundation reports of 1959. These reports pushed for a shift in business schools to include a positivist scientific research focus that opposed the pre-existing broad management training imperatives (Howard et al., 2013). Business schools became heavily focused on analytical research and education in specific disciplines, such as finance or accounting (Mintzberg, 2004). The problem here is that although business schools were including legitimate research methods within their model, the degrees became overly specialized. They overlooked those qualitative skills that may be desirable in a business graduate, including interpersonal skills and general business acumen (Mintzberg, 2004). The result is a curricula that lacks praxis, which means it lacks critical, self-reflective action to allow social change or knowledge that empowers. A business education has become a commodity, only serving the narrow interests of a few, rather than remaining a public good (Tilak, 2008).

This issue of commodification also extends to the research produced by business schools. An expectation exists that business research will have some level of relevance to the business world (Grey, 2007). The expectation is that it will be useful for practitioners and offer some utilitarian return (Boothman, 2000a). This severely limits the directions that academics in a business school can take, especially if they want to look at business, capitalism, or government with a critical eye (Grey, 2007). As a result of this, $\mathrm{PhD}$ students in the business school severely limit themselves on the type of research they pursue, usually ending up with a very narrow focus in terms of topic (Boothman, 2000a; Grey, 2007). 


\section{Losing the Business School}

Those who would like to see the business school leave the university share common beliefs about the nature of these schools. Some would argue, that business schools are obsessed with marketing themselves by using buzz words like "centres of excellence" and "exceptional experience" and this has negatively influenced the rest of the university. Opponents of the business school argue that it is focused too heavily on rankings and certifications. These rankings include those conducted by Businessweek, Maclean's, and the Financial Times. Certification and accreditation agencies include EFMD (The Management Improvement Network), AACSB (Association to Advance Collegiate Schools of Business) and AMBA (The Association of MBAs). Advertisements for business schools purport their uniqueness, assert education as an investment, and emphasize preparedness for the business world and the leveraging of oneself to gain advantage over others (Craig et al., 1999). The focus on competition and rankings has only added to the continued commodification of education within the business school. Other opponents believe the major issue lies with the lack of an appropriate research proposition in business schools (Parker \& Guthrie, 2010). Within the university community the business school has a low standing when it comes to research and is seen mainly as a revenue generator and marketer. These same opponents are likely basing their arguments on a university model that excludes professional or vocational schools.

Those who oppose the inclusion of the business school within the university usually base their opinion on historical and idealistic models of the university, such as the collegial or research-based. Oakeshott (1972) is an example of this type of opponent and believes that a university education should not have an end or objective; it is the process that matters. He is opposed to the idea of a university education that has anything to do with professional or vocational education that provides training to prepare graduates for the working world. Emberley (1997) also feels that a university education is an initiation into the genteel world of scholarly culture that occurs through reading, civility, and conversation. According to him, this is not what a business education currently represents.

The development of the "scholarly culture" is outlined by Emberley (1997) and extends all the way back to the $13^{\text {th }}$ century. He believes that the modern university is being bombarded with social and economic mandates that are killing its scholarly pursuits. In the model Emberley proposes, no room exists for an institution such as the business school because it does not fit the model of a school where scholarly contemplation and dialogue are paramount and where the tentacles of capitalism and politics cannot reach. His version of the university would be funded solely by the state but free to choose its own curriculum. It would not have partnerships with any groups, such as corporations or social justice groups, which might seek to change its objective nature. Emberley's solution is to separate the university into two different institutions: universities and polytechnics. The polytechnic would encompass the pragmatic, vocational education that helps drive economies and prepares students for work in the real world. It focuses on the application of knowledge, practical learning, and preparation of graduates for the working world. The polytechnic model does not require theory and research to legitimize it; rather, research would be focused on finding practical solutions to actual problems. Fortunately, the benefits of reflective action, such as praxis, could still be realized in 
curricula of either model. The classical university and polytechnic models make strong arguments against including the business school in the modern university.

\section{Keeping the Business School}

Critics like Emberley (1997) blame the government and business community for pushing U.S. and Canadian universities to the brink of ruin. He suggests that the university is so pressed to reach its differing social, economic, and political objectives that it has no time to achieve any one of them. Carson (1999) counters Emberley by arguing that focusing solely on the role of the university in modern society is only looking at one aspect of a complex mosaic. He also believes that Emberley is mistaken in what constitutes value in education because it can no longer be defined as a singular outcome. The modern university education should be able to provide a variety of outcomes for students, depending on their motivations. That being said, the role of the modern university in our society is so complex and dynamic, it makes any definition inherently problematic.

A model of the university put forth by Barnett (2000) is likely the most accurate depiction of the complex role of the modern university. He describes it as having an "epistemology for uncertainty", defined by its supercomplexity, and blurring the lines between various fields of study (p. 420). This blurring of lines occurs in both the external and internal environments of the university. Barnett believes there is no longer a need to argue over what should or should not define the university but rather to accept it for what it is. It is an arena of competing and contradictory discourses where voices should not be silenced or expelled, only expanded. Different disciplines should cross over into one another because no one should work within silos. He depicts the university as a world where anything goes as long as enough people are there to support it. The university then becomes a multidisciplinary and self-scrutinizing institution that pushes for inclusion, purpose, and tolerance for all fields, whether inside or outside the physical grounds (Barnett, 2000). This represents a much more open-minded view of the boundaries of the modern university. In Barnett's description the business school would be a welcome addition to the existing super-complexity.

Traditionalist theories used by Oakeshott (1972) and Emberley (1997) attempt to portray the historic university as one that did not concern itself with vocational or pragmatic concerns and was free from political and economic influences. The problem with this argument is that it is flawed and largely not true. As Whitehead (1967/1929) found, at no time has the pursuit of knowledge ever been purely abstract, including some of the earliest examples of universities in Salerno and Cambridge. These schools taught medicine and trained clerks to serve in royal courts, respectively. The existence of vocational roots calls into question the assumptions made by those who would see the separation of the academic and the vocational as the return to an historical ideal. It has to be pointed out that Oakeshott and Emberley's arguments are based as much on idealized visions of the university as they are on historical facts. As Carson (1999) points out, a truly historically developed model of the university is that of the "multiversity," an institution that combines research and vocational education. Since the turn of the 2oth century this model has developed graduate schools, research institutions, and professional programs under multiple disciplines. According to Carson (1999) and others, this is the model that should be used to develop the modern university going forward. 


\section{Analysis and Conclusion}

The makeup of the modern university is a complicated one, offering different meanings to different people. Perhaps Barnett (2000) put it best when he called the modern university a site of "epistemological mayhem," that the university no longer really knows what it means to be a university. Opinions on what should be included or excluded from the curriculum of the modern university are as varied as the population attending those schools. This brings us to the question of the business school and whether or not is should be included under the grand umbrella that the university has become. It is true that the business school may not encompass some of the classical characteristics of the polytechnic or research models outlined by Carson (2007) and Emberley (1997) but it has long been accepted as part of the university landscape.

Changes do need to occur with the philosophy of the business school if it hopes build bridges between itself and other departments within the university. The first change is to appoint more academics working within the business school who also have experience in other university departments. This not only makes them more aware of the overall politics of the school but also provides opportunities for collaborative work and idea sharing. It increases the chances that praxis will take place because individuals will have a better critical perspective to work from in their self-reflection. More well-rounded business scholars would improve the legitimacy and respect for business scholarship with other university faculties.

Changes also need to include how revenue is generated, which by extension includes enrolment. Business schools must ensure that fundraising and business partnerships do not infringe on the objectivity of business researchers. Striving for profitability is a positive endeavour, as long as academic values are maintained (Parker \& Guthrie, 2010). Also, business schools do not necessarily have to be bigger to be better. The drive for larger enrolment has improved revenue and alumni levels for many schools; however, this will have an impact on the quality of education and stress on faculty. Limiting the size and number of business programs and classes would create more engaged students and faculty (Parker \& Guthrie, 2010).

Perhaps the biggest contribution that the business school can offer is to be a site of convergence of ideas and disciplines. Not having theoretical perspectives created in-house means that business researchers would be able to borrow from any theoretical perspective that works for them. An easing of the use of positivist scientific methods would also improve methodology because alternatives could be borrowed from other disciplines that may work better in business scenarios. Quantitative analysis still dominates most of the research within the business school, and stepping away from this would open the door for an expanded use of qualitative methods. Faculty also need to push for the increased use of critical methodologies that examine the negative side of business functions, rather than only praising its benefits. This is when the true benefits of praxis, or reflective action, can be seen.

The business school has been largely successful in legitimizing itself as an academic pursuit (Parker \& Guthrie, 2010). However, practitioners are calling for business students who have a broader knowledge base, including awareness of social and cultural issues, more refined soft skills, and more well-rounded experiences (Boothman, 200ob). Business students are usually described as being overly focused on quantitative or technical 
elements of business and unable to see the bigger picture. Business-school graduates are a product of the shareholder economics featured prominently in these schools causing them to tend to focus on short-term rewards over long-term gains (Boothman, 200ob). Separating the business school from the university would only exacerbate these conditions. The only way to ensure that these business graduates emerge as well-rounded individuals is to expose them to other disciplines, push them to think critically about business practices, and allow them to contribute to curricula. This can only work, however, if the external forces dictating the curriculum and programming within business schools is minimized. These include competition between schools, pandering to business demands, and the commodification of the business education.

All this leads us to revisit the question; should a business school be a part of the modern university? Does the business school offer positive contributions to society as part of the university model? Or, does it matter whether management education occurs in a university setting or in a separate vocational institution? Taking the view of the university as an interdisciplinary arena operating under supercomplexity (Barnett, 2000), symbiotic partnerships can be formed between business school and other departments. Taking the stance that business schools are socializing spaces for future managers (Thrift, 2005), their development into positive members of society becomes important. Crossdisciplinary exposure to ideas from other disciplines such as sociology and history would benefit their development immensely. Universities would continue to benefit fiscally from the inclusion of the business school through both the monetary infusion and the diffusion of business knowledge to the general administration. The business school should have a place at the table, both economically and academically. The sooner we move beyond the limited conceptions of the university set forth by academics like Emberley (1997) and Oakeshott (1972), the sooner we can acknowledge that the business school has already found its proper home.

\section{Notes}

1. British Columbia Ministry of Advanced Education. Retrieved from https://www.cautbulletin.ca/en_article.asp?ArticleID=3109

2. Meritus U. Retrieved from Meritus University: http://www.meritusu.ca/meritus-closure.html

3. University Canada West. Retrieved from https://ucanwest.ca

\section{Acknowledgements}

The author would like to thank Gary Kibbins for his encouragement to write about this topic. Also, thank you to two anonymous reviewers who provided feedback and suggestions to improve earlier versions of the paper. Finally, thank you to the Queen's School of Business for providing the opportunity to obtain a doctoral degree in such an important business field. 


\section{References}

Bach, J. (2010). Praxis. In C. Kridel (Ed.), Encyclopedia of curriculum studies (pp. 681-683). Thousand Oaks, CA: Sage.

Bahti, T. (1992). The injured university. In R. Rand (Ed.). Logomachia: The conflict of the faculties (pp. 57-76). Lincoln, NB: University of Nebraska Press.

Barnett, R. (2000). Realizing the university in an age of supercomplexity. London, UK: Society for Research into Higher Education \& Open University Press.

Bliss, M. (1987). Northern enterprise: Five centuries of Canadian business. Toronto, ON: McClelland \& Stewart.

Boothman, B. E. C. (2000a). Culture of utility: The development of business education in Canada. In B. Austin (Ed.), Capitalizing knowledge: Essays on the history of business education in Canada (pp. 11-86). Toronto, ON: University of Toronto Press.

Boothman, B. E. C. (200ob). Canadian management education at the millennium. In B. Austin (Ed.), Capitalizing knowledge: Essays on the history of business education in Canada (pp. 295-356). Toronto, ON: University of Toronto Press.

Carson, A. S. (1999). Emberley on hot button politics in Canada's universities: A critique. The Canadian Journal of Higher Education, 29(2, 3), 175-200.

Carson, A. S. (2007). Should a for-profit corporation own and operate a university? Philosophy of Management, 6(1), 17-34.

Craig, R. J., Clarke, F. L. K., \& Amernic, J. H. (1999). Scholarship in university business schools - Cardinal Newman, creeping corporatisation and farewell to the "disturber of the peace"? Accounting, Auditing and Accountability Journal, 12(5), 510-524.

Daub, M., \& Buchan, P.B. (1999). Getting down to business: A history of business education at Queen's (1889-1999). Kingston, ON: McGill-Queen's University Press.

Derrida, J. (1992). Mochlos; or, the conflict of the faculties. In R. Rand (Ed.), Logomachia: The conflict of the faculties (pp. 1-34). Lincoln, NB: University of Nebraska Press.

Durand, T., \& Dameron, S. (2008). The future of business schools: Scenarios and strategies for 2020. New York, NY: Palgrave MacMillan.

Emberley, P.C. (1997). Zero tolerance: Hot button politics in Canada's universities. Toronto, ON: Penguin.

Freire, P. (2000). Pedagogy of the oppressed (30th Anniversary Edition). New York, NY: Continuum.

Grey, C. (2007). Possibilities for critical management education and studies. Scandinavian Journal of Management, 23, 463-471.

Howard, T., Lorange, P., \& Sheth, J.N. (2013). The business school in the twenty-first century: Emergent challenges and new business models. Cambridge, UK: Cambridge University Press. 
Kerr, C. (1963). The uses of the university. Cambridge, MA: Harvard University Press.

Lawrence, S., \& Sharma, U. (2002). Commodification of education and academic labour: Using the balanced scorecard in a university setting. Critical Perspectives on Accounting, 13(5/6), 661-677.

Lewis, M. (2005). More than meets the eye: The underside of the corporate culture of higher education and possibilities for a new feminist critique. Journal of Curriculum Theorizing, 21(1), 7-25.

MacIntosh, N. B. (2002). Accounting, accountants and accountability: Poststructuralist positions. London, UK: Routledge.

Mintzberg, H. (2004). Managers, not MBAs: A hard look at the soft practice of managing and management development. San Francisco, CA: Berrett-Koehler.

Oakeshott, M. (1972). Education: The engagement and its frustration. In R.R. Dearden, P.H. Hirst, \& R.S. Peters (Eds.), Education and the development of reason (pp. 19-49). London, UK: Routledge \& Kegan Paul.

Parker, L. D., \& Guthrie, J. (2010). Business schools in an age of globalization. Accounting, Auditing \& Accountability Journal, 23(1), 5-13.

Pelikan, J. (1992). The idea of the university: A re-examination. New Haven, CT: Yale University Press. Press.

Readings, B. (1996). The university in ruins. Cambridge, MA: Harvard University

Sirotnik, K. (1991). Critical inquiry: A paradigm for praxis. In E.D. Short (Ed.), Forms of curriculum inquiry (pp. 243-258). Albany, NY: SUNY Press.

Slaughter, S., \& Leslie, L. (1997). Academic capitalism: Politics, policies and the entrepreneurial university. Baltimore, MD: Johns Hopkins University Press.

Thomas, H., Lorange, P., \& Sheth, J. (2013). The business school in the twenty-first century. Cambridge: Cambridge University Press.

Thrift, N. (2005). Knowing capitalism. London, UK: Sage.

Tierney, W.G., \& Hentschke, G.C. (2007). New players, different game: Understanding the rise of for-profit colleges and universities. Baltimore, MD: Johns Hopkins University Press.

Tilak, J. (2008). Higher education: A public good or a commodity for trade? PROSPECTS, 38(4), 449-466.

Whitehead, A. N. (1967/1929). The aims of education and other essays. New York, NY: Free Press.

\section{Contact Information}

Russell A. Evans

Smith School of Business

Queen's University

russell.evans@queensu.ca 
Russell A. Evans is currently completing his PhD in behavioural accounting at Queen's University in Kingston, Ontario. His dissertation examines the social and cultural implications of the ongoing accountability relationship between First Nations and governmental funding agencies in Canada. Russell holds Master's degrees in accounting from Brock University (2009) and Queen's University (2010). He plans to defend his dissertation in 2016. 